\title{
The role of IFITM3 in the growth and migration of human glioma cells
}

\author{
Bing Zhao ${ }^{*}$, Hongliang Wang, Gang Zong and Ping Li
}

\begin{abstract}
Background: Interferon induced transmembrane protein 3 (IFITM3) is transcribed in most tissues and highly interferon-inducible. However, the role of IFITM3 in cancer is still poorly understood.

Methods: Expression levels ofIFITM3were analyzed in 60 glioma patients by immunohistochemistry (IHC). Following closely, we investigated the phenotype of IFITM3 knockdown on glioma cell growth and tumorigenesis in vitro using lentivirus-mediated loss-of-function strategy.

Results: Depletion of IFITM3in U251 cells dramatically inhibited cell proliferation and colony formation, which demonstrated that reduced IFITM3 protein levels could cause inhibition of tumorigenesis. Knockdown of IFITM3 also induced cell cycle arrest in G0/G1 phase, especially in the sub-G1 phase representing apoptotic cells. In addition, the migration of U251 cells was visibly weakened after IFITM3 knockdown, as determined by Transwell assay.

Conclusions: Our findings provide new evidence that IFITM3 plays an important role in glioma cell growth and migration, suggesting that silencing of IFITM3 by RNA interference (RNAi) may be a potential approach to suppress glioma growth.
\end{abstract}

Keywords: IFITM3, Glioma, RNAi, Growth, Migration

\section{Background}

Glioma is the most common neurosurgical Nerve tumor $[1,2]$. At present, the prognosis of patients with malignant glioma remains very poor, and median survival is generally less than one year from the time of diagnosis, even in the most favorable situations, most patients die within two years $[3,4]$. Numerous studies have shown that gliomas develop as a result of genetic alterations that accumulate with tumor progression and therefore show a great morphological and genetic heterogeneity. Primary and secondary glioblastomas represent distinct entities evolving through different genetic pathways, molecular profile and response to therapy [5]. Therefore, new molecular targets and therapeutic strategies are urgently required for glioma therapy.

Interferon induced transmembrane protein 3 (IFITM3, also known as $1-8 U$ ) was initially identified in a cDNA screen from INF-treated neuroblastoma cell back in 1984 [6] and cloned from a human lymphoid cell cDNA

\footnotetext{
* Correspondence: bingzhaodr@163.com

Department of Neurosurgery, the Second Affiliated Hospital of Anhui Medical University, 678 Fu Rong Road, Hefei 230601, China
}

library [7]. IFITM3 is transcribed in most tissues and is highly interferon-inducible $[7,8]$. Previous studies showed that IFITM3 belongs to a family of murine genes [9], which are short, 2-transmembrane-domain proteins $(5-18 \mathrm{kDa})$ with high core sequence similarity but divergent $\mathrm{N}$ - and C-termini. The human homologues (IFITM1, IFITM2, and IFITM3) are clustered on chromosome 11 within an $18-\mathrm{kb}$ genomic sequence $[7,10,11]$, and mediates cellular processes, including cell adhesion, immune-cell regulation, germ-cell homing and maturation, and bone mineralization [8,11-16].

Recent studies identified possible roles of IFITM genes in carcinogenesis. For example, IFITM1 and IFITM3 were shown to express at higher levels in astrocytoma cells than in normal astrocytes in mice $[11,17,18]$. Furthermore, IFITM1 was identified as a key player in both the carcinogenesis and invasion in patients with glioma [19]. Also, IFITM2 played a crucial role as a p53 independent pro-apoptotic gene in regulating cancer cellular pathways to death [20]. Researchers first isolated the IFITM3 gene from tumor tissue and severely inflamed mucosa in the colons of patients with ulcerative colitis,
C Biomed Central

(c) 2013 Zhao et al.; licensee BioMed Central Ltd. This is an open access article distributed under the terms of the Creative Commons Attribution License (http://creativecommons.org/licenses/by/2.0), which permits unrestricted use, distribution, and reproduction in any medium, provided the original work is properly cited. 
describing it as a preferential marker for ulcerative colitisassociated colon cancer [21,22]. In addition, IFITM3 expression has been found to be up-regulated in gastric cancer, colorectal tumors, and so on [23-25].

In this study, we showed the positive correlation between the expression levels of IFITM3 and pathological grades of glioma by IHC. However, the precise function and underlying mechanism of IFITM3 in glioma pathogenesis remain unclear. To study the role of IFITM3 in glioma, we employed lentivirus-mediated short hairpin RNA (shRNA) to knock down IFITM3 in human glioma cell line U251. The effects of IFITM3 knockdown on cell growth and migration were investigated.

\section{Methods}

\section{Materials}

Dulbecco's modified Eagle's medium (DMEM) and fetal bovine serum (FBS) were obtained from Hyclone (Logan, Utah, USA). Lipofectamine 2000, TRIzol $^{\circ}$ Reagent was purchased from Invitrogen (Carlsbad, CA, USA). M-MLV Reverse Transcriptase was purchased from Promega (Madison, WI, USA; cat. M1705). All other chemicals were obtained from Sigma (St. Louis, MO, USA). The antibodies used were as follows: anti-IFITM3 (1:50 dilution; Sigma/ SAB1410086).

\section{Immunohistochemistry (IHC)}

We studied 60 glioma patients who had been surgically treated in Department of Neurosurgery, the Second Affiliated Hospital of Anhui Medical University, Hefei 230601, China. For IHC, 60 pairs of resected glioma tissues were fixed in $10 \%$ formalin solution and embedded in paraffin. Histological slices of $3 \mathrm{~mm}$ were prepared, then were deparaffined in xylene, and rehydrated with graded ethanol. Endogenous peroxidase was blocked with $0.3 \% \mathrm{H}_{2} \mathrm{O}_{2}$ in methanol for $20 \mathrm{~min}$ at room temperature (RT). Following antigen retrieval, the sections were blocked with 5\% BSA for $20 \mathrm{~min}$ at RT and then probed with 1:300 rabbit anti-IFITM3 at $4^{\circ} \mathrm{C}$ overnight. After washing, the sections were incubated with Histostain $\bigcirc$ R-Plus 3rd Gen IHC Detection Kit (Invitrogen/85-9073) at RT for $1 \mathrm{~h}$, and visualized using the peroxidase conjugated streptavidin and diaminobenzidine, followed by counterstaining with Mayer's haematoxylin. The IFITM3 antibody was replaced by PBS in negative controls. IHC staining were evaluated by a pathologist blinded to all clinical data. Samples were scored positive when more than $10 \%$ of the cells reacted with the anti-IFITM3 antibody and presented cytoplasm staining.

\section{Cell culture}

Human glioma cell line U251 and human embryonic kidney cell line $293 \mathrm{~T}$ were obtained from American Type Culture Collection (ATCC). Cells were maintained in DMEM supplemented with $10 \%$ heat-inactivated FBS and 100 units $/ \mathrm{ml}$ penicillin/streptomycin at $37^{\circ} \mathrm{C}$ in humidified atmosphere of $5 \% \mathrm{CO}_{2}$.

\section{Construction of IFITM3 shRNA lentivirus vector and cell infection}

The following oligonucleotide was synthesized. The negative control small interfering RNA (siRNA) was 5'TTCTCCGAACGTGTCACGT-3'. IFITM3 siRNA was 5'-GCTGGAATTCATGAATCACACTGTCCAAAC-3' . The stem-loop-stem oligos (shRNAs) were synthesized, annealed, and ligated into the Nhe I/Pac I-linearized pFH-L vector. The lentiviral-based shRNA-expressing vectors were confirmed by DNA sequencing. The generated plasmids were named as pFH-L-shIFITM3 or -shCon. Recombinant lentiviral vectors and packaging vectors were then transfected into $293 \mathrm{~T}$ cells. Supernatants containing lentivirus expressing IFITM3 shRNA or control shRNA were harvested $72 \mathrm{~h}$ after transfection. Then, the lentiviruses were purified using ultracentrifugation, and the titer of lentiviruses was determined. U251 cells were infected with the lentivirus constructs at multiplicity of infection $(\mathrm{MOI})=10$ and mock-infected cells were used as negative controls. To demonstrate specific knockdown of IFITM3, these experiments are also being repeated by using another two shRNAs (5'-CCAACTATGAGATGCTCAAGGCTC GAGCCTTGAGCATCTCATAGTTGGTTTTTT-3' and 5' -CCTCATGACCATTCTGCTCATCTCGAGATGAGC AGAATGGTCATGAGGTTTTT-3') against IFITM3 to get comparable results.

\section{RT-PCR}

Total RNA was extracted from U251 cells 5 days after infection using TRIzol $^{\circ}$ Reagent. cDNA was synthesized using M-MLV Reverse Transcriptase. In brief, a mixture containing $1.5 \mu \mathrm{g}$ of total RNA, $0.75 \mu \mathrm{g}$ oligo-dT primer (Shanghai Sangon) and nuclease-free water in a total volume of $13.5 \mu \mathrm{l}$ was heated at $70^{\circ} \mathrm{C}$ for $5 \mathrm{~min}$ and then cooled on ice for another $5 \mathrm{~min}$. The mixture was supplemented with $4 \mu \mathrm{l}$ M-MLV buffer, $1.25 \mu \mathrm{l}$ dNTP, $0.5 \mu \mathrm{l}$ RNasin and $0.75 \mu \mathrm{M}$-MLV-RT up to a final volume of $20 \mu \mathrm{l}$, followed by incubation at $42^{\circ} \mathrm{C}$ for $60 \mathrm{~min}$.

\section{Real-time quantitative PCR}

Real-time quantitative PCR analysis was performed using SYBR Green Master Mix Kit on BioRad connect Real-Time PCR platform. In brief, each PCR reaction mixture containing $10 \mu \mathrm{l}$ of $2 \times$ SYBR GreenMaster Mix, $1 \mu \mathrm{l}$ of sense and antisense primers $(5 \mu \mathrm{mol} / \mu \mathrm{l})$ and $1 \mu \mathrm{l}$ of cDNA (10 ng), was run for 45 cycles with denaturation at $95^{\circ} \mathrm{C}$ for $15 \mathrm{~s}$, annealing at $60^{\circ} \mathrm{C}$ for $30 \mathrm{~s}$ and extension at $72^{\circ} \mathrm{C}$ for $30 \mathrm{~s}$ in a total volume of $20 \mu \mathrm{l}$. For relative quantification, $2^{-\Delta \Delta C T}$ was calculated and used as an indication of the relative expression levels, which 
was calculated by subtracting CT values of the control gene from the CT values of IFITM3. The primer sequences for PCR amplification of IFITM3 gene were 5'-TGTCCA AACCTTCTTCTCTCC-3' and 5'-CGTCGCCAACCAT CTTCC-3'. $\beta$-actin was applied as an internal control. The primer sequences of $\beta$-actin were $5^{\prime}$-GTGGA CATCCGCAAAGAC-3' and 5' - AAAGGGTGTAACG CAA CTA-3'.

\section{MTT assay}

U251 cells were trypsinized, resuspended, seeded into 96-well plate with a concentration of 2000 cells per well, and incubated at $37^{\circ} \mathrm{C} 3$ days post lentivirus infection. The number of viable cells was measured at daily intervals (day 1, 2, 3, 4 and 5). At each time point, $10 \mu \mathrm{l}$ of $5 \mathrm{mg} / \mathrm{ml} \mathrm{MTT} \mathrm{(Dingguo} \mathrm{Biotechnology)} \mathrm{was} \mathrm{added,} \mathrm{and}$ incubation was continued for $3 \mathrm{~h}$. Then the medium was removed carefully and $100 \mu \mathrm{l}$ of acidified isopropanol (in $0.01 \mathrm{M} \mathrm{HCl}$ ) was added at the end of incubation. The absorbance was measured at $595 \mathrm{~nm}$ on the spectrophotometer.

\section{Colony formation assay}

A total of $200 \mathrm{U} 251$ cells were seeded in 6-well plates after 3 days of lentivirus infection. The medium was changed at regular time intervals. After 11 days of cultureat $37^{\circ} \mathrm{C}$, the natural colonies were washed with PBS and fixed with $4 \%$ paraformaldehyde for $30 \mathrm{~min}$ at room temperature. The colonies were then stained with Giemsa for $10 \mathrm{~min}$, washed with water and air-dried. The total number of colonies with more than 50 cells was counted under fluorescence microscopy.

\section{Fluorescence-activated cell sorting analysis}

The cell cycle distribution was analyzed using flow cytometry with PI staining. In brief, $1.5 \times 10^{5}$ cells that infected with lentivirus for 4 days were seeded in $6-\mathrm{cm}$ dishes and allowed to culture for $40 \mathrm{~h}$ at $37^{\circ} \mathrm{C}$. Cells were harvested after tripsinization, washed with PBS, and fixed with $70 \%$ cold ethanol. Cells were then collected by centrifugation, resuspended in PBS containing $100 \mu \mathrm{g} / \mathrm{ml}$ of DNase-free RNase and $40 \mu \mathrm{g} / \mathrm{ml} \mathrm{PI}$, and incubated for $1 \mathrm{~h}$ at $37^{\circ} \mathrm{C}$. A total of $1.0 \times 10^{4}$ fixed cells were analyzed by FACS can (Becton-Dickinson, Franklin Lakes, NJ, USA).

\section{Cell migration assay}

U251 cells were infected with Lv-shIFITM3 for 4 days, and the in vitro migration ability was determined using a Transwell chamber (Corning, NY, USA). Briefly, cells were seeded into the upper chamber of the transwell plates $(8.0 \mu \mathrm{m}$ pore, Corning Costar, Cambridge, MA) with $3.0 \times 10^{4}$ cells/well in $200 \mu \mathrm{l}$ of serum-free medium, and $500 \mu \mathrm{l}$ medium containing $10 \%$ FBS was added to the lower chamber as a chemoattractant. After incubation for $24 \mathrm{~h}$ at $37^{\circ} \mathrm{C}$ in $5 \% \mathrm{CO}_{2}$, the cells remaining on the upper surface of the filter were removed, and those that invaded to the lower compartment were fixed with Methanol and stained with crystal violet. Cells were counted visually in 5 random fields under light
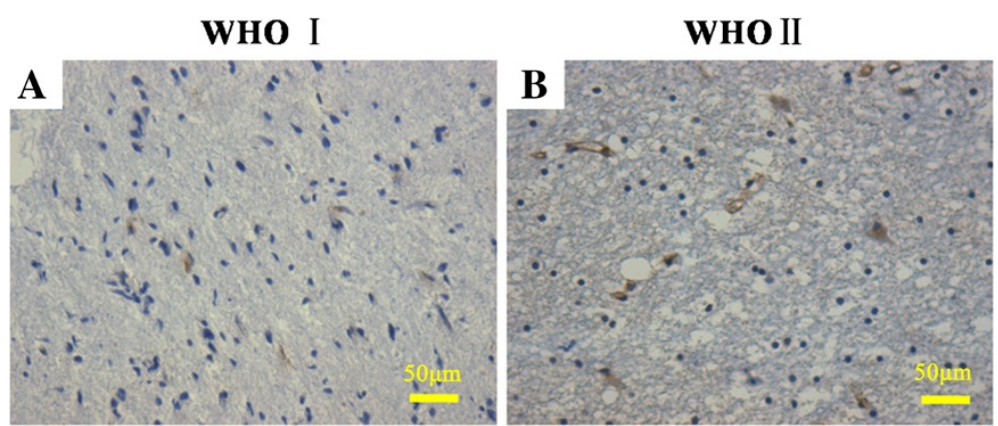

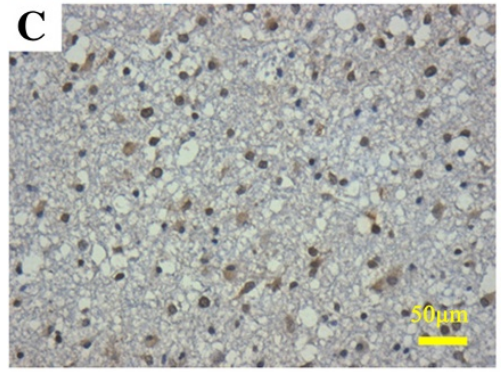

WHO III

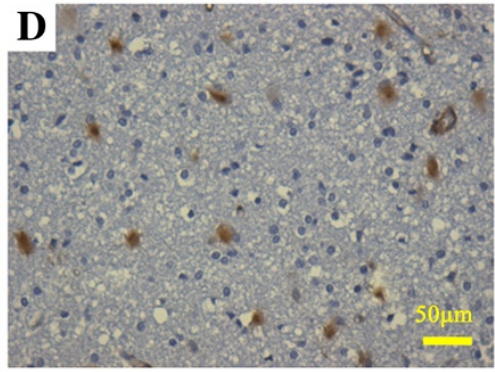

WHO IV

Figure 1 Representative immunohistochemical staining for IFITM3 in patients with different grade glioma. A pilocytic astrocytoma (WHO I); B astrocytoma (WHO II); C anaplastic astrocytoma (WHO III); D multiple glioblastoma (WHO IV). Original magnification $200 \times$. 
Table 1 The relationship between the incidence of immunoreactivity for IFITM3 in human glioma tissue specimens and the histological grades

\begin{tabular}{cccccc}
\hline \multirow{2}{*}{ Sample } & N & \multicolumn{2}{c}{ Expression of IFITM3 } & Chi-square & P value \\
\cline { 3 - 4 } & Negative & Positive & & \\
\hline $\begin{array}{c}\text { Low-grade gliomas } \\
(\text { II, II) }\end{array}$ & 28 & $7(25.0 \%)$ & $21(75.0 \%)$ & & \\
$\begin{array}{c}\text { High-grade gliomas } \\
\text { (III, IV) }\end{array}$ & 32 & $2(6.3 \%)$ & $30(93.8 \%)$ & & \\
\hline
\end{tabular}

$\mathrm{N}$ : number of samples.

microscope (10 $\times$ objective lens). In addition, invaded cells were dissociated, lysed and quantified at $570 \mathrm{~nm}$ using spectrophotometer.

\section{Statistical analysis}

All data were expressed as mean \pm SD of three independent experiments, in which each assay was performed in triplicate. The results were analyzed statistically using the chi-square test for the relationship between the incidence of immunoreactivity for IFITM3 and the histological grades using GrafPad Prism version 5.0. The
Student's $t$-test was used to evaluate the differences between the control cells and IFITM3 knockdown cells using SPSS 13.0 software. $P<0.05$ was considered as statistically significant.

\section{Results and discussion}

Overexpression of IFITM3 in human glioma tissues

To evaluate the role of IFITM3in human glioma, IHC was performed to analyze the expression levels of IFITM3 in 60 glioma patients (grade I:7; grade II:25; grade III:17; grade IV:11). According to the World Health Organization (WHO) classification, low-grade gliomas encompass grade I and grade II tumors with the least malignant phenotypes, while high-grade gliomas encompass grade III (anaplastic astrocytoma, anaplastic oligoastrocytoma, and anaplastic oligodendroglioma) and grade IV (glioblastoma [GBM]) tumor with the most malignant phenotype [26]. Compared with the low grade glioma groups (Figure 1A and B), IFITM3 positive staining was mostly observed in high grade glioma (Figure $1 C$ and D). IFITM3 expression level was increased with the histological grade of glioma (Table $1, \mathrm{P}<0.05$ ). We also provided positive control and

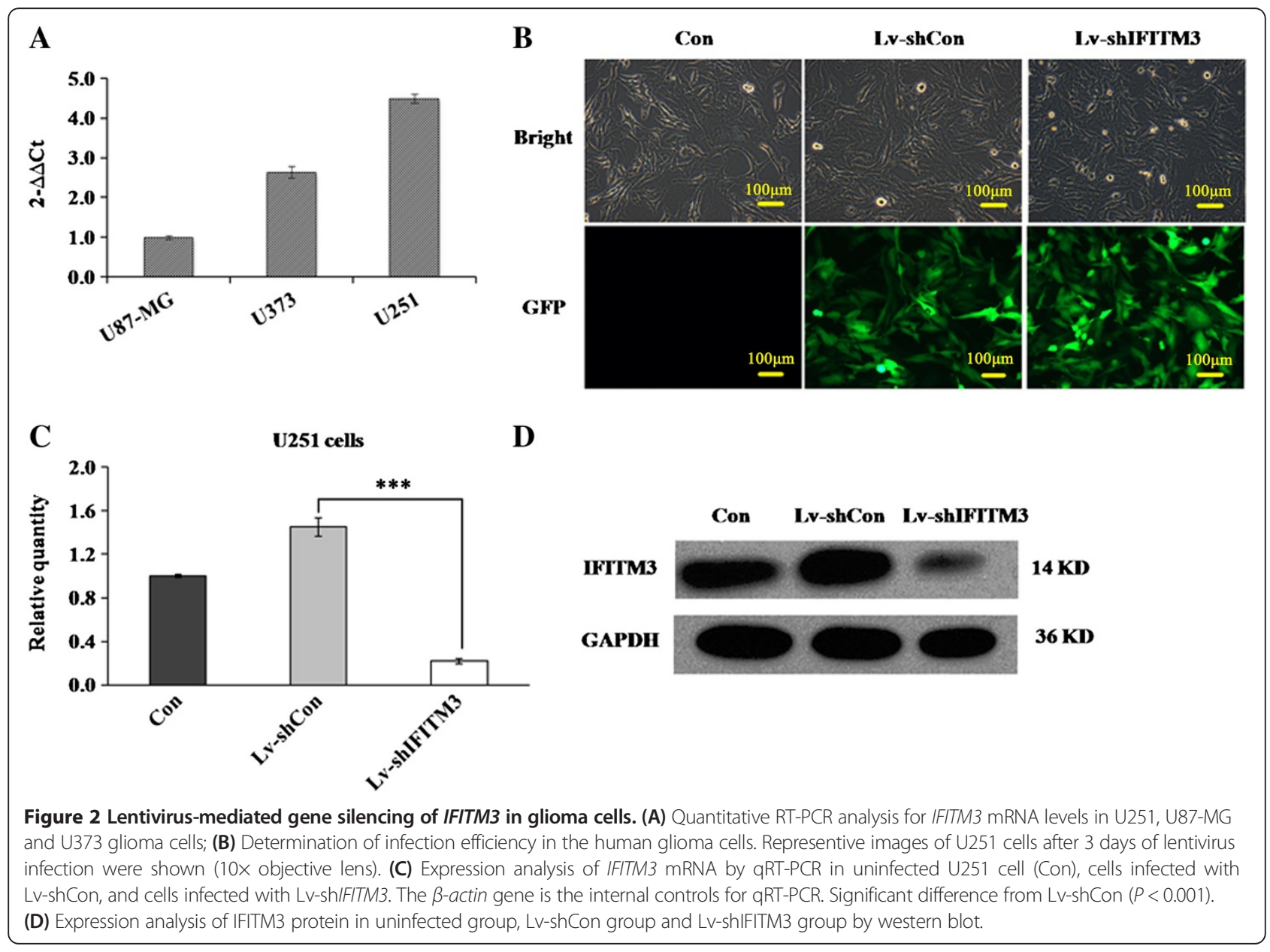


negative control in which the corresponding IFITM3 antibody was replaced by PBS, as shown in Additional file 1: Figure S1. These data clearly indicate that IFITM3 is specifically overexpressed in glioma tissues, and its high expression may contribute to the pathogenesis of glioma.

Knockdown of IFITM3 in U251 cells by lentivirus infection Human glioma cells of different transformation degrees, as represented by $\mathrm{U} 373$ astrocytoma (WHO grade III), U87-MG and U251 glioblastoma multiforme (WHO grade IV) were selected to detect IFITM3 expression. As shown in Figure 2A, high expression levels of IFITM3 were observed in all three cells. U251 cells, derived from a high-grade glioblastoma, were used for the following loss-of-function investigation. We constructed a lentiviral vector system to express siRNA targeting IFITM3 and to express GFP as a reporter gene. To determine the efficacy of recombinant lentiviruses, U251 cells infected with Lv-shIFITM3 and Lv-shCon were observed under a fluorescence microscope. More than $90 \%$ of the cells expressed GFP after $72 \mathrm{~h}$ infection (Figure 2B), which indicated high-efficiency infection by Lv-shIFITM3. To verify that the IFITM3 gene was silenced by Lv-shIFITM3, we determined the mRNA levels in uninfected, Lv-shCon and Lv-shIFITM3-infected cells by qRT-PCR. Cell infected with Lv-shIFITM3 exhibited significant decreased IFITM3 mRNA levels, by $84.8 \%$ reduction in U251 cells, compared with Lv-shCon-infected and uninfected cells (Figure 2C, $P<0.001)$. The similar result was observed in U251 cells infected with another two shRNA stargeting IFITM3, respectively (Additional file 2: Figure S2 A, $P<0.001$ ). To confirm the silencing of IFITM3, western blot was used using IFITM3 antibodies. Compared with uninfected and Lv-shCon infected cells, the IFITM3 protein level was significantly decreased in U251 cells infected with the Lv-shIFITM3 (Figure 2D). Similarly, only weak band was detected in U251 cells infected with another two shRNAs targeting IFITM3, respectively, while the high expression of IFITM3 was not affected in cells

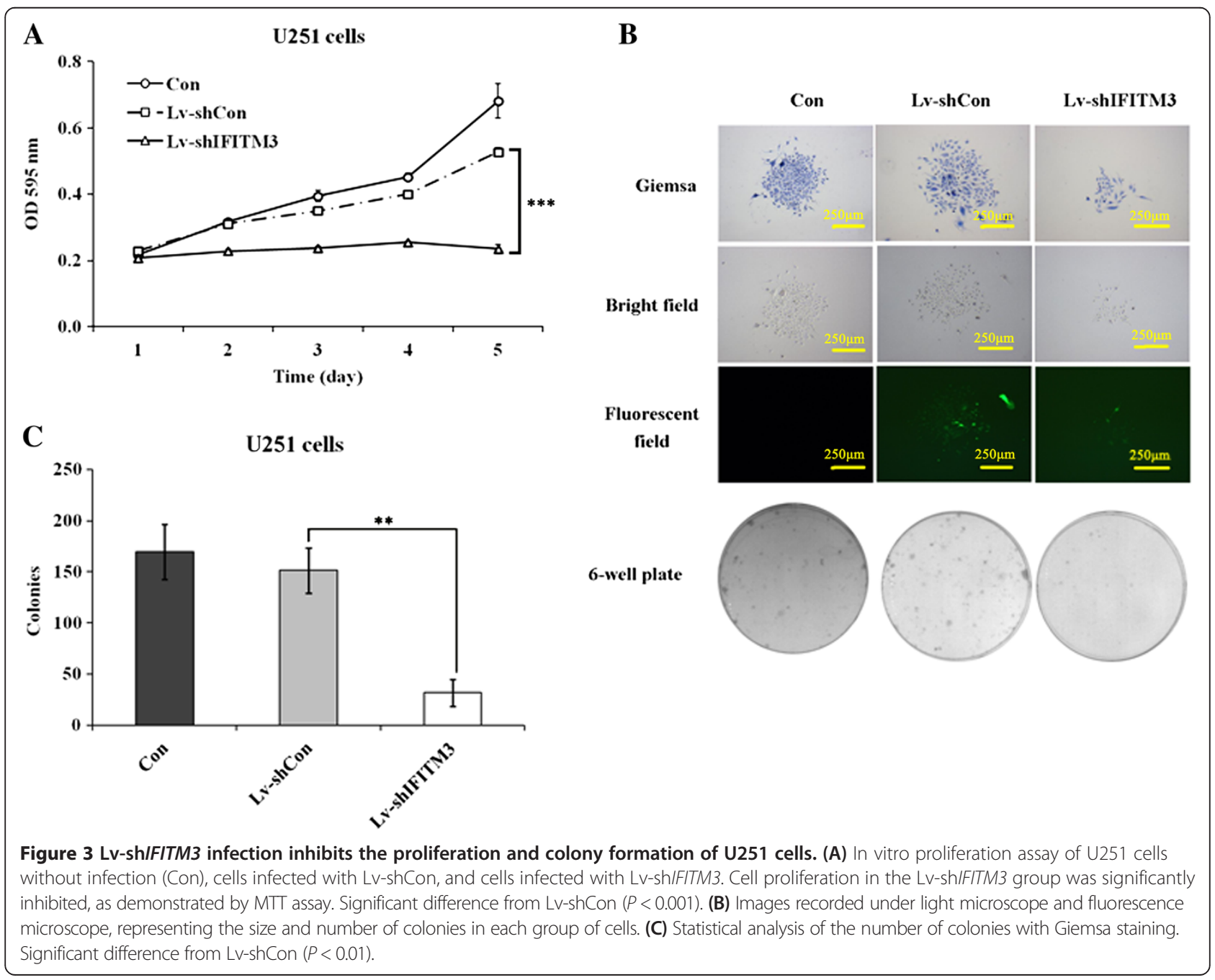


infected with Lv-shCon compared with control cells (Additional file 2: Figure S2 B).

\section{Knockdown of IFITM3 inhibited cell proliferation}

MTT assay was performed to investigate the effect of IFITM3 knockdown on cell proliferation. The growth curve obtained from the MTT assay indicated that the proliferative ability of Lv-shIFITM3-infected cells was significantly decreased, by $55.2 \%$ reduction in U251 cells, when compared with that of Lv-shCon-infected cells $(P<0.001$, Figure 3A). The similar results could be seen in Additional file 2: Figure S2 C, the proliferative ability of Lv-shIFITM3-S2-infected and Lv-shIFITM3-S3-infected cells was significantly decreased, respectively. These results indicate that knockdown of IFITM3 by RNAi could inhibit the proliferation of glioma cells.

\section{Downregulation of IFITM3 suppressed colony formation}

To determine whether IFITM3 has any impact on the colony-forming capacity of glioma cells, colony formation assay was performed. Our data indicated that the number and size of colonies formed fromLv-shIFITM3infected cells were strongly decreased, by $78.8 \%$ reduction in U251 cells, compared with Lv-shCon-infected cells (Figure $3 \mathrm{~B}$ and $\mathrm{C}, P<0.01$ ), suggesting that the reduced expression of IFITM3 could significantly inhibit colony formation in glioma cells.

\section{Depletion of IFITM3 induced cell cycle arrest as well as apoptosis}

To elucidate whether knockdown of IFITM3 inhibits cell growth by affecting cell cycle progression, we assessed the cell cycle distribution in U251 cells by flow cytometry (Figure 4A). As shown in Figure 4B, compared to control groups, cell population in the Lv-shIFITM3 group displayed a significant decrease in $\mathrm{S}$ phase (Lv-shCon $56.58 \% \pm 0.36 \%$ vs $60.07 \% \pm 0.90 \%, P<0.01)$, and a significant increase in G0/G1 phase (Lv-shCon $56.58 \% \pm 0.36 \%$ vs $60.07 \% \pm 0.90 \%, P<0.05)$. Accumulation of cells in the sub-G1 fraction was clearly observed in the Lv-shIFITM3 group compared to $\mathrm{Lv}$-shCon group ( $\mathrm{Lv}$-shCon $1.09 \% \pm$ $0.07 \%$ vs $3.35 \% \pm 0.32 \%, P<0.01$ ) (Figure $4 \mathrm{C}$ ). Taken

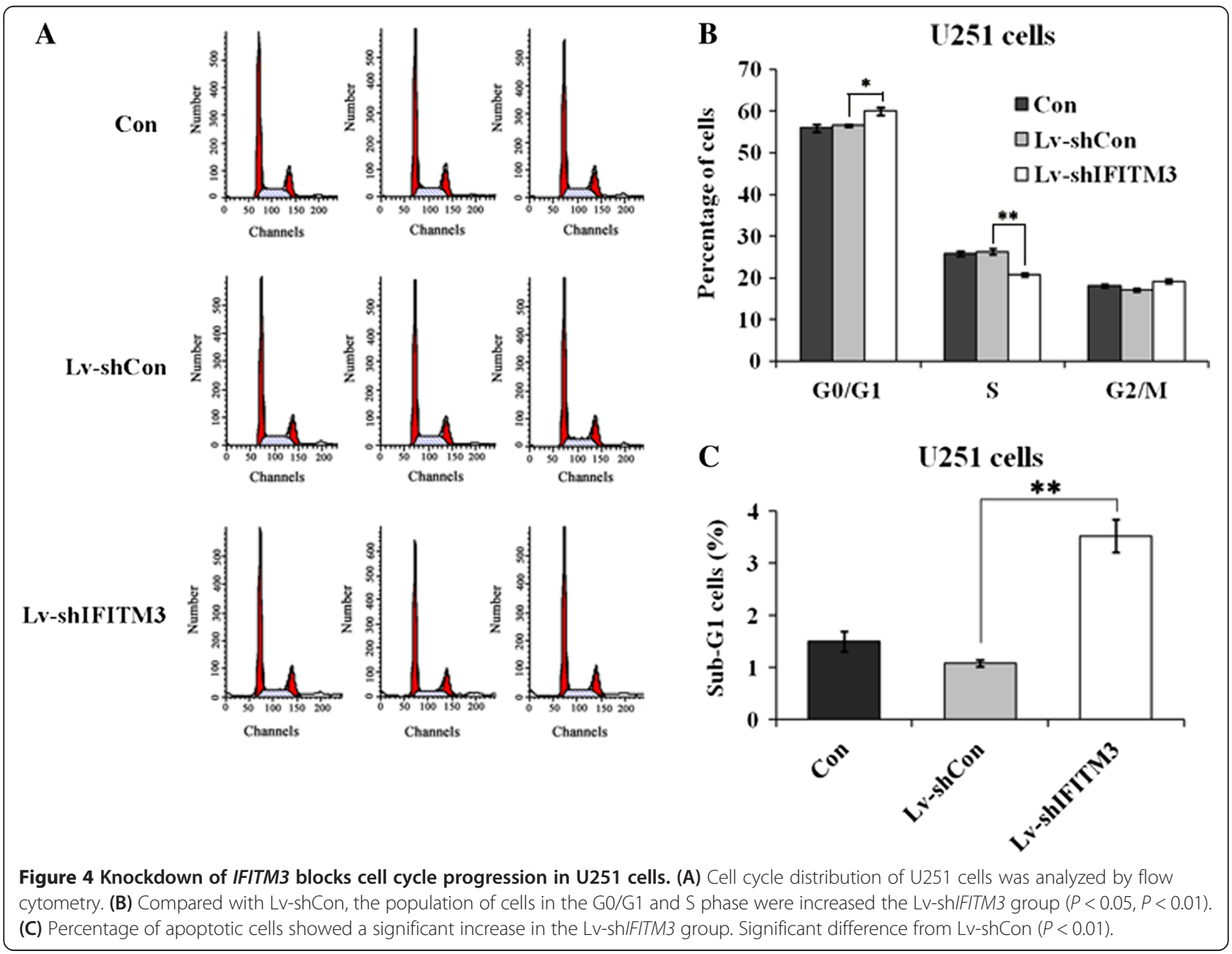


together, these data suggest that IFITM3 could modulate cell growth via cell cycle regulation as well as apoptosis.

\section{Downregulation of IFITM3 attenuated cell migration}

To detect whether knockdown of IFITM3 affects the migration of glioma cells, Transwell migration assay was performed to assess the proportion of U251 cells which migrated through polycarbonate membranes following 4 days of lentivirus infection. We found that IFITM3 knockdown reduced the number of invaded cells accounting for $65.5 \%$ reduction in U251 cells (Figure 5A and B, $P<0.01)$. In addition, the colorimetric assay showed that the motility capability of U251 cells were retained after Lv-shIFITM3 infection $(P<0.01$, Figure 5 C).

\section{Conclusions}

Glioma is triggered by a series of point mutations and genetic alterations that progressively cause normal cells to transform into precancerous cell which could become more dysplastic, resulting in carcinoma foci [27]. At present, the identification of useful markers for the diagnosis of human glioma is a major goal in cancer research, which also provides valuable information in tumor pathogenesis. We analyzed the expression of IFITM3 in human glioma specimens by immunohistochemistry and found the expression levels of IFITM3 were up-regulated in varying degrees and positively correlated with glioma of pathological grade I II and III IV $(\mathrm{P}<0.05)$. Meanwhile, recent studies have also shown that IFITM3 plays a prominent role in tumor development and can be used as a tumor biomarker [21-25]. However, the precise role of IFITM3 in glioma pathogenesis remains unknown.

In recent few years the discovery of RNAi, a powerful tool to induce loss-of-function phenotypes through the posttranscriptional silencing of gene expression, has provided new possibilities for cancer therapy [28-30]. In our study, lentivirus-mediated RNAi was used to knock down IFITM3 in human glioma cells. The siRNA targeting IFITM3, which expressed from the recombinant lentivirus, induced efficient and specific inhibition of endogenous IFITM3 mRNA in U251 cells. Simultaneously, depletion of IFITM3 led to significant reduced cell proliferation, colony formation and cell migration in U251 cells. Thus, this study confirms a crucial role of IFITM3 in glioma tumorigenesis, suggesting IFITM3 as an oncogene in human glioma.

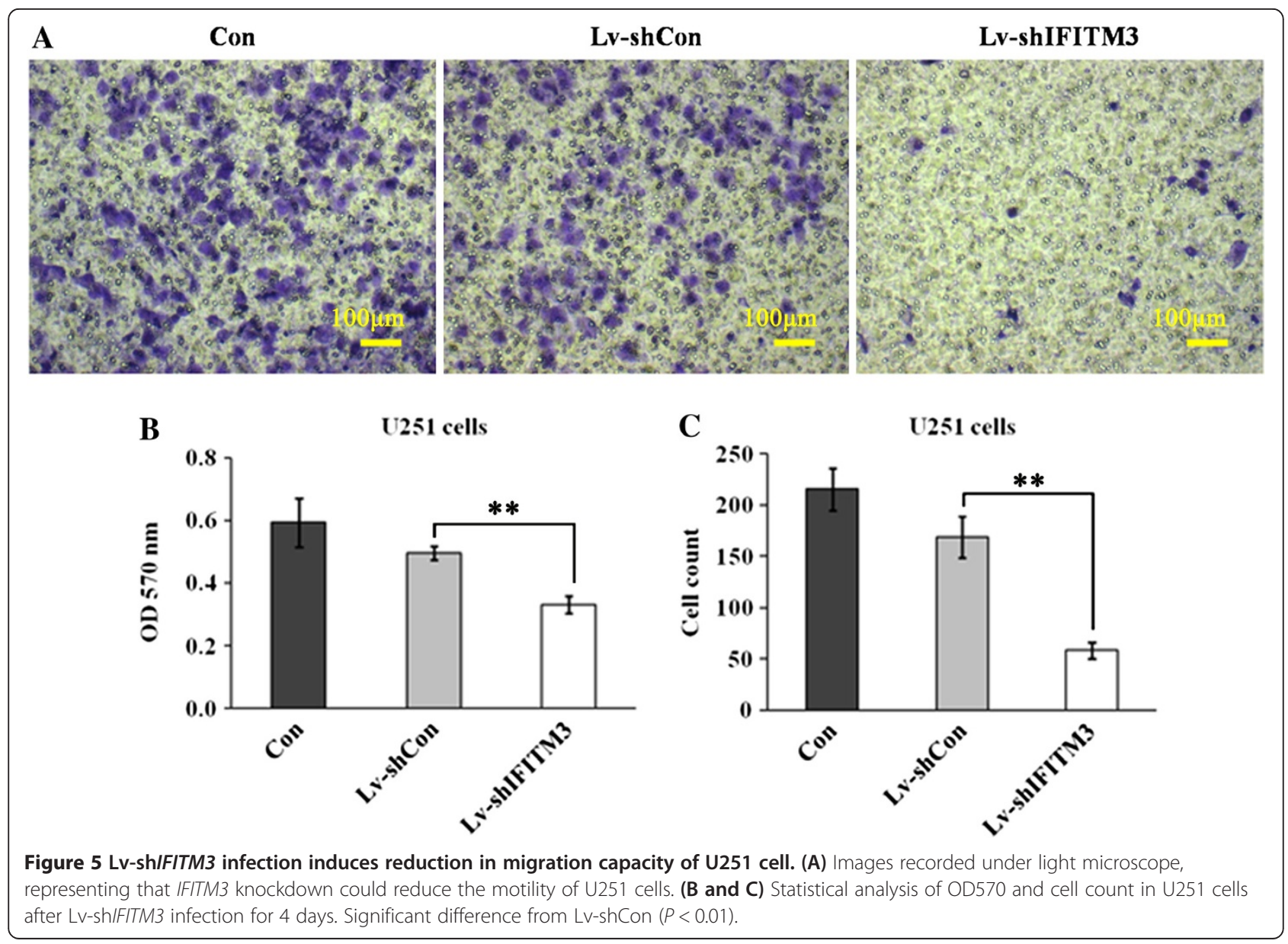


Moreover, cell cycle analysis indicated that knockdown of IFITM3 remarkably induced U251 cells accumulation in G0/G1 phase, especially in sub-G1 phase, which represents cell apoptosis [31]. Together, IFITM3 may promote human glioma growth by inducing cell cycle arrest and apoptosis. Based on the IFITM3 belong to 2-transmembrane-domain proteins $(5-18 \mathrm{kDa})$ with high core sequence similarity but divergent $\mathrm{N}$ - and $\mathrm{C}$-termini, we suggest IFITM3 as a growth regulator in glioma, and it may be involved in the control of transport essential raw materials for DNA and enzymic synthesis process in cell cycle progression.

However, some studies indicated IFITM3 plays an important role in inhibiting tumor development. For instance, El-Tanani et al. [32] found that IFITM3 in breast cancer physically interacts with $O P N$ and reduces $O P N$ mRNA expression, which mediates cancer cell adhesion, cell invasion and colony formation. Similar situation has come under observation in human melanoma, and it is deemed dynamic promoter methylation adds an additional layer of complexity to the IFN- $\alpha$ key response genes like IFITM3 be required for comprehensive control of the IFN- $\alpha$ response [33,34]. Therefore, we think the roles of IFITM3 in various cancers possibly depend on tumor growth microenvironment. Under normal physiological circumstances, IFITM3 could be in a balance regulating by different signal pathways.

Furthermore, local invasion is one of the primary reasons for clinical treatment failure in malignant gliomas. Recently, there has been increasing evidence regarding specific molecules that determine the aggressiveness and invasion potential of high grade astrocytic tumors [35]. In our study, we found IFITM3 knockdown significantly reduced the migration capacity of U251 cells, indicating that IFITM3 might play an essential role in glioma metastasis. However, further experiments are needed to elucidate the mechanism of IFITM3 in glioma cell growth and migration.

To sum up, knockdown of IFITM3 by RNAi successfully reduced cell proliferation and migration, and promoted apoptosis in glioma cells. Our results provide new evidence for the involvement of IFITM3 in carcinogenesis, and suggest that RNAi-directed IFITM3 silencing may be a potent therapeutic tool in glioma.

\section{Consent}

Written informed consent was obtained from the patient for the publication of this report and any accompanying images.

\section{Additional files}

Additional file 1: Figure S1. Positive control and negative control for the specificity of the anti-IFITM3 antibody. Representative immunohistochemical staining for IFITM3 in glioma (A) and colon cancer tissues (C).
Immunohistochemical staining for the corresponding IFITM3 antibody was replaced by PBS in glioma tissues (B).

Additional file 2: Figure S2. (A) Determination of knockdown efficiency in the U251 cells infected with LV-shIFITM3-S2 and LV-ShIFITM3-S3 by qRT-PCR. Significant difference from $L v$-shCon $(P<0.001)$. (B) Expression analysis of IFITM3 protein in uninfected group, LV-shCon group and LV-shIFITM3-S2 group and LV-shIFITM3-S3 group by western blot. (C) The effect of IFITM3-S2 and IFITM3-S3 on the proliferation of U251 cells. Significant difference from $L V$-shCon $(P<0.001)$.

\section{Competing interests}

The authors declare that they have no competing interests.

\section{Authors' contributions}

BZ conceived, coordinated and designed the study, and contributed to the acquisition, analysis and interpretation of data and drafted the manuscript. HW and GZ performed the experiment and involved in drafting the article. $B Z$ and $P L$ accepts full responsibility for the work and/or the conduct of the study, had access to the data, and oversaw the decision to publish. All authors read and approved the final manuscript.

\section{Acknowledgement}

This study was supported by National Natural Science Foundation of China (Grant No. 81072066).

Received: 11 June 2013 Accepted: 12 December 2013

Published: 27 December 2013

\section{References}

1. Wen PY, Kesari S: Malignant gliomas in adults. N Engl J Med 2008, 359:492-507.

2. McLendon R, Friedman A, Bigner D, Van Meir EG, Brat DJ, Mastrogianakis GM, Olson JJ, Mikkelsen T, Lehman N, Aldape K, et al: Comprehensive genomic characterization defines human glioblastoma genes and core pathways. Nature 2008, 455:1061-1068.

3. Liu BL, Cheng JX, Zhang X, Zhang W: Controversies concerning the application of brachytherapy in central nervous system tumors. J Cancer Res Clin Oncol 2010, 136:173-185.

4. Stupp R, Mason WP, Van den Bent MJ, Weller M, Fisher B, Taphoorn MJ, Belanger K, Brandes AA, Marosi C, Bogdahn U, et al: Radiotherapy plus concomitant and adjuvant temozolomide for glioblastoma. $N$ Engl J Med 2005, 352:987-996.

5. Pollo B: Neuropathological diagnosis of brain tumours. Neurol Sci 2011, 32(Suppl 2):S209-S211.

6. Friedman RL, Manly SP, McMahon M, Kerr IM, Stark GR: Transcriptional and posttranscriptional regulation of interferon-induced gene expression in human cells. Cell 1984, 38:745-755.

7. Lewin AR, Reid LE, McMahon M, Stark GR, Kerr IM: Molecular analysis of a human interferon-inducible gene family. Eur J Biochem 1991, 199:417-423.

8. Siegrist F, Ebeling M, Certa U: The small interferon-induced transmembrane genes and proteins. J Interferon Cytokine Res 2011, 31:183-197.

9. Lange UC, Saitou M, Western PS, Barton SC, Surani MA: The fragilis interferon-inducible gene family of transmembrane proteins is associated with germ cell specification in mice. BMC Dev Biol 2003, 3:1.

10. Evans SS, Collea RP, Appenheimer MM, Gollnick SO: Interferon-alpha induces the expression of the L-selectin homing receptor in human $B$ lymphoid cells. J Cell Biol 1993, 123:1889-1898.

11. Tanaka SS, Yamaguchi YL, Tsoi B, Lickert H, Tam PP: IFITM/Mil/fragilis family proteins IFITM1 and IFITM3 play distinct roles in mouse primordial germ cell homing and repulsion. Dev Cell 2005, 9:745-756.

12. Tanaka SS, Nagamatsu G, Tokitake Y, Kasa M, Tam PP, Matsui Y: Regulation of expression of mouse interferon-induced transmembrane protein like gene-3, Ifitm3 (mil-1, fragilis), in germ cells. Dev Dyn 2004, 230:651-659.

13. Smith RA, Young J, Weis JJ, Weis JH: Expression of the mouse fragilis gene products in immune cells and association with receptor signaling complexes. Genes Immun 2006, 7:113-121.

14. Saitou M, Barton SC, Surani MA: A molecular programme for the specification of germ cell fate in mice. Nature 2002, 418:293-300.

15. Brass AL, Huang IC, Benita Y, John SP, Krishnan MN, Feeley EM, Ryan BJ, Weyer JL, Van der Weyden L, Fikrig E, et al: The IFITM proteins mediate 
cellular resistance to influenza A H1N1 virus, West Nile virus, and dengue virus. Cell 2009, 139:1243-1254.

16. Yount JS, Moltedo B, Yang YY, Charron G, Moran TM, Lopez CB, Hang HC: Palmitoylome profiling reveals S-palmitoylation-dependent antiviral activity of IFITM3. Nat Chem Biol 2010, 6:610-614.

17. Seyfried NT, Huysentruyt LC, Atwood JA 3rd, Xia Q, Seyfried TN, Orlando R. Up-regulation of NG2 proteoglycan and interferon-induced transmembrane proteins 1 and 3 in mouse astrocytoma: a membrane proteomics approach. Cancer Lett 2008, 263:243-252.

18. Wylie C: IFITM1-mediated cell repulsion controls the initial steps of germ cell migration in the mouse. Dev Cell 2005, 9:723-724.

19. Yu F, Ng SS, Chow BK, Sze J, Lu G, Poon WS, Kung HF, Lin MC: Knockdown of interferon-induced transmembrane protein 1 (IFITM1) inhibits proliferation, migration, and invasion of glioma cells. J Neurooncol 2011, 103:187-195.

20. Daniel-Carmi V, Makovitzki-Avraham E, Reuven EM, Goldstein I, Zilkha N, Rotter V, Tzehoval $E$, Eisenbach $L$ : The human $1-8 D$ gene (IFITM2) is a novel p53 independent pro-apoptotic gene. Int I Cancer 2009, 125:2810-2819.

21. Hisamatsu T, Watanabe M, Ogata H, Ezaki T, Hozawa S, Ishii H, Kanai T, Hibi T: Interferon-inducible gene family 1-8U expression in colitis-associated colon cancer and severely inflamed mucosa in ulcerative colitis. Cancer Res 1999, 59:5927-5931.

22. Wu F, Dassopoulos T, Cope L, Maitra A, Brant SR, Harris ML, Bayless TM, Parmigiani G, Chakravarti S: Genome-wide gene expression differences in Crohn's disease and ulcerative colitis from endoscopic pinch biopsies: insights into distinctive pathogenesis. Inflamm Bowel Dis 2007, 13:807-821.

23. Seo GS, Lee JK, Yu JI, Yun KJ, Chae SC, Choi SC: Identification of the polymorphisms in IFITM3 gene and their association in a Korean population with ulcerative colitis. Exp Mol Med 2010, 42:99-104.

24. Andreu P, Colnot S, Godard C, Laurent-Puig P, Lamarque D, Kahn A, Perret C, Romagnolo B: Identification of the IFITM family as a new molecular marker in human colorectal tumors. Cancer Res 2006, 66:1949-1955.

25. Li D, Peng Z, Tang H, Wei P, Kong X, Yan D, Huang F, Li Q, Le X, Xie K. KLF4-mediated negative regulation of IFITM3 expression plays a critical role in colon cancer pathogenesis. Clin Cancer Res 2011, 17:3558-3568.

26. Louis DN, Ohgaki H, Wiestler OD, Cavenee WK, Burger PC, Jouvet A, Scheithauer BW, Kleihues P: The 2007 WHO classification of tumours of the central nervous system. Acta Neuropathol 2007, 114:97-109.

27. Ohgaki H, Dessen P, Jourde B, Horstmann S, Nishikawa T, Di Patre PL, Burkhard C, Schuler D, Probst-Hensch NM, Maiorka PC, et al: Genetic pathways to glioblastoma: a population-based study. Cancer Res 2004, 64:6892-6899.

28. Brummelkamp TR, Bernards R, Agami R: A system for stable expression of short interfering RNAs in mammalian cells. Science 2002, 296:550-553.

29. Elbashir SM, Harborth J, Lendeckel W, Yalcin A, Weber K, Tuschl T: Duplexes of 21-nucleotide RNAs mediate RNA interference in cultured mammalian cells. Nature 2001, 411:494-498.

30. Pecot CV, Calin GA, Coleman RL, Lopez-Berestein G, Sood AK: RNA interference in the clinic: challenges and future directions. Nat Rev Cancer 2011, 11:59-67.

31. Jun DY, Park HS, Kim JS, Park W, Song BH, Kim HS, Taub D, Kim YH: 17Alpha-estradiol arrests cell cycle progression at G2/M and induces apoptotic cell death in human acute leukemia Jurkat T cells. Toxicol Appl Pharmacol 2008, 231:401-412.

32. El-Tanani MK, Jin D, Campbell FC, Johnston PG: Interferon-induced transmembrane 3 binds osteopontin in vitro: expressed in vivo IFITM3 reduced OPN expression. Oncogene 2010, 29:752-762.

33. Brem R, Oraszlan-Szovik K, Foser S, Bohrmann B, Certa U: Inhibition of proliferation by $1-8 \mathrm{U}$ in interferon-alpha-responsive and non-responsive cell lines. Cell Mol Life Sci 2003, 60:1235-1248.

34. Scott R, Siegrist F, Foser $S$, Certa U: Interferon-alpha induces reversible DNA demethylation of the interferon-induced transmembrane protein-3 core promoter in human melanoma cells. J Interferon Cytokine Res 2011, 31:601-608.

35. Liu L, Wu J, Ying Z, Chen B, Han A, Liang Y, Song L, Yuan J, Li J, Li M: Astrocyte elevated gene-1 upregulates matrix metalloproteinase- 9 and induces human glioma invasion. Cancer Res 2010, 70:3750-3759.

doi:10.1186/1471-2377-13-210

Cite this article as: Zhao et al:: The role of IFITM3 in the growth and migration of human glioma cells. BMC Neurology 2013 13:210.

\section{Submit your next manuscript to BioMed Central and take full advantage of:}

- Convenient online submission

- Thorough peer review

- No space constraints or color figure charges

- Immediate publication on acceptance

- Inclusion in PubMed, CAS, Scopus and Google Scholar

- Research which is freely available for redistribution 